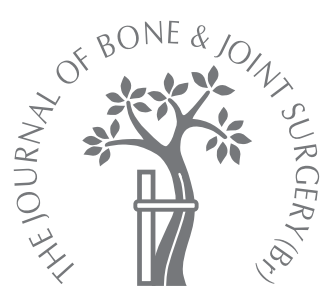

L. R. Goodrich, C. Hidaka, P. D. Robbins, C. H. Evans, A. J. Nixon

From Comparative Orthopaedics Laboratory, Cornell University, Ithaca, USA

- L. R. Goodrich, DVM, PhD, Assistant Professor of Equine Surgery and Lameness Colorado State University, College of Veterinary Medicine, Fort Collins, Colorado 80523 , USA.

= C. Hidaka, MD, Assistant Scientist

Hospital for Special Surgery, 535 East 70th Street, New York New York 10021, USA

= P. D. Robbins, PhD, Professor Department of Orthopaedic Surgery, and Department of Molecular Genetics and Biochemistry

University of Pittsburgh School of Medicine, W1246 Biomedical Science Tower, Pittsburgh,

Pennsylvania, USA.

In C. H. Evans, DSc, PhD, Robert W. Lovett Professor of Orthopaedic Surgery Brigham and Women's Hospital, Center for Molecular Orthopaedics, B1-152, 221 Longwood Avenue, Boston, Massachusetts 02115, USA.

ㅍ. J. Nixon, BVSc, MS, Professor of Orthopaedic Surgery

Comparative Orthopaedics Laboratory, C3-176 Veterinary Medical Center, Cornell University, Ithaca, New York 14853, USA.

Correspondence should be sent to Professor A. J. Nixon; e-mail: ajn1@cornell.edu

(C2007 British Editorial Society of Bone and Joint Surgery doi:10.1302/0301-620X.89B5 $18343 \$ 2.00$

$J$ Bone Joint Surg [Br] 2007;89-B:672-85. Received 30 June 2006; Accepted after revision 8 December 2006

\title{
Genetic modification of chondrocytes with insulin-like growth factor-1 enhances cartilage healing in an equine model
}

Gene therapy with insulin-like growth factor-1 (IGF-1) increases matrix production and enhances chondrocyte proliferation and survival in vitro. The purpose of this study was to determine whether arthroscopically-grafted chondrocytes genetically modified by an adenovirus vector encoding equine IGF-1 (AdIGF-1) would have a beneficial effect on cartilage healing in an equine femoropatellar joint model.

A total of 16 horses underwent arthroscopic repair of a single $15 \mathrm{~mm}$ cartilage defect in each femoropatellar joint. One joint received $2 \times 10^{7}$ AdIGF-1 modified chondrocytes and the contralateral joint received $2 \times 10^{7}$ naive (unmodified) chondrocytes. Repairs were analysed at four weeks, nine weeks and eight months after surgery. Morphological and histological appearance, IGF-1 and collagen type II gene expression (polymerase chain reaction, in situ hybridisation and immunohistochemistry), collagen type II content (cyanogen bromide and sodium dodecyl sulphate-polyacrylamide gel electrophoresis), proteoglycan content (dimethylmethylene blue assay), and gene expression for collagen type I, matrix metalloproteinase (MMP)-1, MMP-3, MMP-13, aggrecanase-1, tissue inhibitor of matrix metalloproteinase-1 (TIMP-1) and TIMP-3 were evaluated.

Genetic modification of chondrocytes significantly increased IGF-1 mRNA and ligand production in repair tissue for up to nine weeks following transplantation. The gross and histological appearance of IGF-1 modified repair tissue was improved over control defects. Gross filling of defects was significantly improved at four weeks, and a more hyaline-like tissue covered the lesions at eight months. Histological outcome at four and nine weeks post-transplantation revealed greater tissue filling of defects transplanted with genetically modified chondrocytes, whereas repair tissue in control defects was thin and irregular and more fibrous. Collagen type II expression in IGF-1 gene-transduced defects was increased 100 -fold at four weeks and correlated with increased collagen type II immunoreaction up to eight months.

Genetic modification of chondrocytes with AdIGF-1 prior to transplantation improved early (four to nine weeks), and to a lesser degree long-term, cartilage healing in the equine model.

The equine model of cartilage healing closely resembles human clinical cartilage repair. The results of this study suggest that cartilage healing can be enhanced through genetic modification of chondrocytes prior to transplantation.

The limited repair potential of adult articular cartilage continues to restrict rehabilitation following trauma. The considerable efforts which have been made to establish cell transplantation and tissue-engineered cartilage repair systems reflects the limited impact of local manipulation of cartilage and marrow elements. ${ }^{1-5}$ Focal cartilage defects can occur subsequent to trauma or osteochondritis dissecans. ${ }^{6-8}$ Various methods, such as microfracture, abrasion chondroplasty, and forage, have been used in attempts to stimulate the healing process, but none have been able to achieve predictable restoration of durable articular cartilage. ${ }^{9}$ Focal chondral defects can negatively affect the cartilage surrounding it, and may lead to degenerative arthritis and pain. ${ }^{10-12}$ Over 20 million people suffer from osteoarthritis in the USA alone, where annual medical costs exceed $\$ 60$ billion. ${ }^{10,13-15}$

Chondrocyte transplantation is one of the more successful techniques used to treat cartilage defects in humans and in equine models. $1,3,8,9,16$ Immature chondrocytes have been used in equine and other animal models because they improve cartilage repair, remain synthetically active, and can withstand harvesting and storage. ${ }^{3,16-18}$ Previous studies in horses, and investigations using smaller animal models have shown that chondrocyte implan- 
tation significantly improves cartilage repair compared with leaving defects empty or filling them only with biological matrices. ${ }^{3,13,14,16,19,20}$ Despite these improvements, the resulting hyaline-like tissue rarely extends through the entire thickness of the cartilage. Furthermore, it may require nine months to two years in humans and eight months or more in research animals before full activity can be resumed, and repairs frequently deteriorate over time. ${ }^{3,8}$

Insulin-like growth factor-1 (IGF-1) is arguably the most important anabolic growth factor for regulating chondrocyte metabolic functions in normal and diseased cartilage. $^{21-23}$ Its primary function in cartilage is to balance proteoglycan synthesis with matrix degradation to maintain functional cartilage. ${ }^{23}$ We have previously shown that the transcriptional response of IGF-1 in cartilage defects is minimal at two and 16 weeks post injury. ${ }^{24}$ The deficiency of this crucial growth factor may contribute to the lack of healing response following articular cartilage injury, and play a role in precipitating osteoarthritic degradation. ${ }^{25-29}$ We have also previously shown that adding exogenous IGF-1 improves or 'rescues' the repair process by stimulating matrix production, type II collagen synthesis, and preservation of the chondrocyte phenotype. ${ }^{5,30-32}$ Given the temporal flux in IGF-1 expression, combined with its ability to augment proteoglycan and type II collagen production, it is apparent that early and extended IGF-1 supplementation would enhance matrix synthesis in transplanted chondrocytes, and potentially also influence chondrocytic differentiation of cells originating from the subchondral bone pool, both mechanisms that are likely to accelerate articular cartilage healing.

Genetically modifying chondrocytes prior to transplantation can induce IGF-1 protein production. We have shown that chondrocytes and synoviocytes cultured in vitro can be genetically modified with a single exposure to adenoviral IGF-1 constructs (AdIGF-1). ${ }^{32,33}$ AdIGF-1 modification of chondrocytes induced a significant increase in IGF-1 mRNA expression, concomitant secretion of therapeutic IGF-1 ligand concentrations for at least 28 days, and resulted in increased matrix biosynthesis and maintenance of the chondrocyte phenotype. ${ }^{32}$ Studies in rabbits also suggest that IGF-1 gene transduction of chondrocytes using non-viral mechanisms enhances some of the histological repair characteristics of cartilage defects implanted with transduced cells. ${ }^{34}$ Previously we have reported that ex vivo gene modification of chondrocytes is highly compatible with the technical aspects of cartilage biopsy collection and chondrocyte isolation for culture prior to transplantation, and that such modification can improve cartilage repair. ${ }^{35}$ In the present study we investigated the use of chondrocytes genetically modified to over-express IGF-1 for the enhancement of cartilage repair.

Compared with other animal models, the equine cartilage defect repair model is particularly relevant to cartilage healing in humans. The thickness of equine cartilage, including the thickness of the calcified cartilage and the subchondral bone plate, is closer to that of humans than any other animal used for experimental studies of cartilage repair. $^{36}$ Furthermore, arthroscopic joint surgery has largely replaced arthrotomy in the horse, just as it has in humans. Also, the horse is the only species other than human that currently undergoes clinical chondrocyte transfer therapy. ${ }^{37}$ Critical-sized defects in the equine model are reported to be approximately $6 \mathrm{~mm}$ to $9 \mathrm{~mm}$ in diameter, $^{38,39}$ and $12 \mathrm{~mm}$ to $15 \mathrm{~mm}$ defects have typically been used in studies of chondrocyte grafting. The biochemical, histological and biomechanical characteristics of equine repair and cartilage tissue are particularly well defined. 5,11,16,40-42 These considerations make the equine model particularly relevant to human chondrocyte transplantation and cartilage repair.

The purpose of this study was to determine, in a large animal model, whether chondrocytes genetically modified with AdIGF-1 would have a beneficial effect on cartilage healing, based on the histological, morphological, biochemical and molecular characteristics of the repair tissue and the surrounding adjacent cartilage. We hypothesised that the transplantation of AdIGF-1-modified chondrocytes into large defects on the femoral trochlea of horses would induce elevated IGF-1 expression in repair tissue for substantial periods; that elevated IGF-1 expression would result in increased collagen type II and aggrecan expression in the repair tissue; and lastly that the molecular changes induced by AdIGF-1-modified chondrocytes would accelerate the healing properties of cartilage repair tissue compared with repair tissue implanted with naive chondrocytes.

\section{Materials and Methods}

Adenovirus vector. A recombinant adenoviral vector carrying an 888-bp segment of equine IGF-1 cDNA (AdIGF1) was constructed by Cre-lox recombination and propagated in a transformed embryonic kidney cell line, as described previously. ${ }^{43}$ The AdIGF-1 vector was an E1-, partial E3-construct based on the Ad serotype 5 genome, and contained the cytomegalovirus immediate/early promoter enhancer, the 888-bp IGF-1 sequence encoding the entire equine prepropeptide, and the IGF-1A carboxylterminal extension peptide and the SV 40 polyA signal. ${ }^{44}$ Viral particles were propagated and purified. ${ }^{32}$ The total viral titre was determined spectrophotometrically, and infectious titre carrying the IGF-1 transgene was estimated to be $1 \%$ of this total.

Chondrocyte harvest and graft preparation. Chondrocytes from articular cartilage were harvested from the femoropatellar joints of neonatal male foals (one to two days old) at postmortem, and kept frozen in liquid nitrogen until ready for use. ${ }^{45}$ Preparation of the graft with adenovirusmodified chondrocytes was performed as previously described, ${ }^{35}$ except that the cells were incubated with 20000 infectious units per cell (200 multiplicity of infection) AdIGF-1 for four hours, or as a control with no virus. This 
Table I. Scoring system used to evaluate gross lesions

\begin{tabular}{|c|c|}
\hline Analysis & Qualifications (\%) \\
\hline \multicolumn{2}{|c|}{ Area covered with hyaline repair tissue } \\
\hline 0 & $\begin{array}{l}\text { Normal: smooth, hya- } \\
\text { line }\end{array}$ \\
\hline 1 & $>75$ normal \\
\hline 2 & 50 to 75 normal \\
\hline 3 & $<50$ normal \\
\hline \multicolumn{2}{|c|}{ Area of defect covered } \\
\hline 0 & 100 of defect \\
\hline 1 & $>75$ \\
\hline 2 & 50 to 75 \\
\hline 3 & $<50$ \\
\hline \multicolumn{2}{|c|}{ Graft-recipient tissue integration } \\
\hline 0 & 100 of perimeter \\
\hline 1 & $>75$ \\
\hline 2 & 50 to 75 \\
\hline 3 & $<50$ \\
\hline \multicolumn{2}{|c|}{ Cross-sectional subchondral bone attachment } \\
\hline 0 & 100 attachment \\
\hline 1 & $>75$ \\
\hline 2 & 50 to 75 \\
\hline 3 & $<50$ \\
\hline \multicolumn{2}{|c|}{ Cross-sectional perimeter attachment } \\
\hline 0 & Both sides attached \\
\hline 1 & One side detached \\
\hline 2 & Two sides detached \\
\hline \multicolumn{2}{|c|}{ Cross-sectional filling } \\
\hline 1 & Above \\
\hline 0 & Even \\
\hline 1 & $>75$ \\
\hline 2 & 50 to 75 \\
\hline 3 & $<50$ \\
\hline
\end{tabular}

Table IIII. Scoring parameters for assessment of insulin-like growth factor-1 and type II collagen mRNA in situ hybridisation

\begin{tabular}{cl}
\hline Score & Qualifications \\
\hline 0 & $\begin{array}{l}\text { Large amount of silver grains } \\
\text { localised over cells }\end{array}$ \\
1 & $\begin{array}{l}\text { Moderate amount of silver } \\
\text { grains }\end{array}$ \\
2 & Small amount of silver grains \\
3 & No detectable silver grains \\
\hline
\end{tabular}

dose of AdIGF-1 has previously been established as optimal for therapeutic gene transfer to equine chondrocytes. ${ }^{32}$ After genetic modification, chondrocytes were suspended in fibrinogen that was harvested from plasma collected from each horse undergoing experimental surgery. ${ }^{3}$ The suspension of transduced chondrocytes and autogenous fibrinogen was polymerised within the created cartilage defect at the time of the surgical procedure using calcium-activated bovine thrombin (500 U/ml, Sigma, St Louis, Missouri).

Operative procedure. A total of 16 normal adult horses (all female), between two and six years old (mean 4 years), underwent experimental cartilage repair using a protocol
Table II. Scoring parameters for assessment of histological sections

\begin{tabular}{|c|c|}
\hline Analysis & Qualifications (\%) \\
\hline \multicolumn{2}{|c|}{ Defect filling } \\
\hline 1 & 111 to 125 \\
\hline 0 & 91 to 110 \\
\hline 1 & 76 to 90 \\
\hline 2 & 51 to 75 \\
\hline 3 & 26 to 50 \\
\hline 4 & $<25$ \\
\hline \multicolumn{2}{|c|}{ Chondrocyte predominance } \\
\hline 0 & All \\
\hline 1 & Many \\
\hline 2 & Some \\
\hline 3 & None \\
\hline \multicolumn{2}{|c|}{ Perilesional cloning } \\
\hline 0 & None \\
\hline 1 & Some \\
\hline 2 & Many \\
\hline 3 & All \\
\hline \multicolumn{2}{|c|}{ Subchondral bone attachment } \\
\hline 0 & 91 to 100 \\
\hline 1 & 76 to 90 \\
\hline 2 & 51 to 75 \\
\hline 3 & 26 to 50 \\
\hline 4 & $<25$ \\
\hline \multicolumn{2}{|c|}{ Perimeter attachment } \\
\hline 0 & Complete \\
\hline 1 & Gap, one side \\
\hline 2 & Gap, both sides \\
\hline \multicolumn{2}{|c|}{ Toluidine staining } \\
\hline 0 & 91 to 100 \\
\hline 1 & 76 to 90 \\
\hline 2 & 51 to 75 \\
\hline 3 & 26 to 50 \\
\hline \multicolumn{2}{|c|}{ Surface fibrillation } \\
\hline 0 & None \\
\hline 1 & Slight \\
\hline 2 & Moderate \\
\hline 3 & Severe \\
\hline \multicolumn{2}{|l|}{ Tidemark } \\
\hline 0 & Complete \\
\hline 1 & $>50$ \\
\hline 2 & $<50$ \\
\hline 3 & None \\
\hline
\end{tabular}

approved by the Institutional Animal Care and Use Committee. Synovial fluid was withdrawn and bilateral femoropatellar joint arthroscopy and chondrocyte grafting was performed as previously described, ${ }^{3,31}$ except that genetically-modified chondrocytes were used in one limb (randomly chosen) and naive (unmodified) chondrocytes were placed into the defect in the contralateral limb. Each horse served as its own control. The $15 \mathrm{~mm}$ diameter experimental defect in the lateral trochlear ridge extended down to, but not through, the subchondral bone. Specifically, a $15 \mathrm{~mm}$ diameter fluted spade-bit cutter with a sharpened perimeter skirt (Special Devices, Grass Valley, 
Table IV. Scoring parameters for assessment of insulin-like growth factor- 1 and type II collagen immunohistochemistry

\begin{tabular}{clcl}
\hline Score $\mathbf{1}$ & $\begin{array}{l}\text { Surface area with positive } \\
\text { immunostaining (\%) }\end{array}$ & Score 2 & Intensity \\
\hline 0 & 75 to 100 & 0 & Intense \\
1 & 50 to 74 & 1 & Moderate \\
2 & 25 to 49 & 2 & Light \\
3 & $<25$ & 3 & Absent \\
\hline \multicolumn{2}{l}{ Total score for each sample = score 1 + score 2 }
\end{tabular}

California) was inserted into the joint using a protective steel sleeve, then placed flat onto the lateral trochlear ridge, and the hyaline and calcified cartilage was removed in its entirety using frequent arthroscopic verification of the depth of the defect. Any residual cartilage tags or calcified cartilage at the perimeter of the defect were carefully removed with a small curette to leave a smooth bone surface. The subchondral bone surface was then dried using $\mathrm{CO}_{2}$ gas and approximately $2 \times 10^{7}$ cells in $0.5 \mathrm{ml}$ of fibrinogen were injected into the defect until the fibrin graft completely filled the defect to the level of the surrounding normal articular cartilage.

Peri-operative pain management included morphine delivered through an epidural catheter, and the nonsteroidal anti-inflammatory agent phenylbutazone. The horses were observed for any signs of pain or lameness. No exercise was allowed for the first six weeks post-operatively. Thereafter, the rehabilitation protocol consisted of increasing intervals of walking for five weeks, followed by unlimited pasture exercise. Standard cytological examination was performed on synovial fluid obtained from both femoropatellar joints just prior to surgery and on days four, seven, 14 and 28 post-surgery.

Gross evaluation and specimen collection. Animals were killed by an overdose of barbiturate at four weeks (four horses), nine weeks (four horses), and eight months (eight horses). The femoropatellar joints were removed, overlying tissues dissected aseptically, and the lateral and medial trochlear ridges exposed and examined. The gross appearance of the repair tissue was evaluated by two investigators (AJN, CH) who were unaware of the treatment group. A composite healing score was given based on six categories (Table I). Each category was also evaluated independently. Scores from both evaluators were averaged for statistical analysis.

Tissue collection from various sites within the joint was identical for each time point, with the addition of a $5 \mathrm{~mm}$ punch biopsy of cartilage from the lesion, the surrounding cartilage (perilesion: tissue within a $10 \mathrm{~mm}$ circumference of the lesion), and remote cartilage (taken from the medial trochlear ridge) for proteoglycan assay in eight-month samples. For all joints, lesion, perilesion and remote tissue was collected, snap frozen in liquid nitrogen, and kept frozen at $-80^{\circ} \mathrm{C}$ for later RNA analysis and biochemical assays. A
$3 \times 10 \mathrm{~mm}$ segment of synovial membrane and underlying capsule from the cranial (or lateral) aspect of the femoropatellar joint was removed and fixed in $4 \%$ paraformaldehyde. Lastly, a $5 \mathrm{~mm} \times 20 \mathrm{~mm}$ osteochondral block was collected through the central third of the lesion, extending $3 \mathrm{~mm}$ to $5 \mathrm{~mm}$ into the perilesional tissue for histological, histochemical, immunohistological and in situ hybridisation studies. This specimen was fixed in $4 \%$ paraformaldehyde and decalcified in 10\% ethylenediamine-tetra-acetic acid (EDTA).

Histological, histochemical, immunohistological and in situ hybridisation studies. The osteochondral blocks of repair tissue were embedded in paraffin, sectioned at $6 \mu \mathrm{m}$, and stained with haematoxylin and eosin to evaluate tissue morphology, and with toluidine blue to assess the distribution of proteoglycan in the pericellular matrix. The synovial membrane and sections of decalcified cartilage-bone were evaluated by two investigators ( $\mathrm{AJN}, \mathrm{CH}$ ) unaware of the treatment group, using various parameters (Table II). For each tissue type, the total scores from the two evaluators were averaged for statistical analysis.

In situ hybridisation. The presence and spatial distribution of IGF-1 and type II collagen mRNA was evaluated by in situ hybridisation. ${ }^{46,47}$ Briefly, radiolabelled probes $\left(\left[{ }^{35} S\right]-\right.$ uridinetriphosphate-labelled) were synthesised from a genetic sequence of 201 base pairs of cDNA encoding exons 1 to 7 of equine type IIB procollagen mRNA, corresponding to positions 138 to 339 of the available equine gene published in GENBANK $^{48}$ (accession number U62528). Equine-specific IGF-1 riboprobes were generated from a 270-bp cDNA encoding exons 1 to 3 of equine IGF1A precursor mRNA, corresponding to positions 1 to 270 of the available equine coding sequence (GENBANK accession number U85272). After stringent washing, sections were dehydrated, dipped in Nuclear Track (NT)B-2 emulsion (Eastman Kodak, Rochester, New York), and exposed for 14 days. The sections were counterstained with haematoxylin, examined under light and dark-field microscopy, and assigned a score based on intensity of hybridisation to the antisense probe (Table III).

Immunohistochemistry. The presence of IGF-1 ligand and type II collagen was assessed by immunohistochemistry. Sections were treated with $5 \mu \mathrm{g} / \mathrm{ml}$ of testicular hyaluronidase at $37^{\circ} \mathrm{C}$ for 60 minutes, and endogenous peroxidases were exhausted with hydrogen peroxide and methanol. After blocking with normal goat serum, sections were incubated with polyclonal rat anti-bovine type II collagen primary antibody (1:100) (courtesy of Dr Michael Cremer, Veterans Administration Hospital, Memphis, Tennessee) or rabbit anti-IGF-1 antibody (Gro-Pep, Adelaide, Australia). Secondary antibody (supersensitive multilink: BioGenex, San Ramone, California) was applied, followed by streptavidin-conjugated peroxidase label (BioGenex) to catalyse chromagen development in diaminobenzidine tetrachloride (DAB from Sigma-Aldrich, St Louis, Missouri; other immunohistochemistry reagents from BioGenex). The 


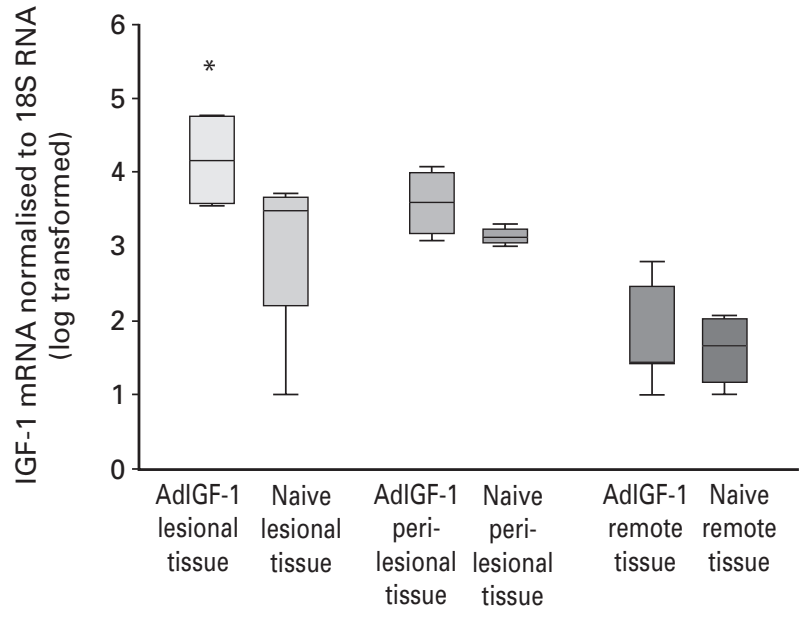

Fig. 1a

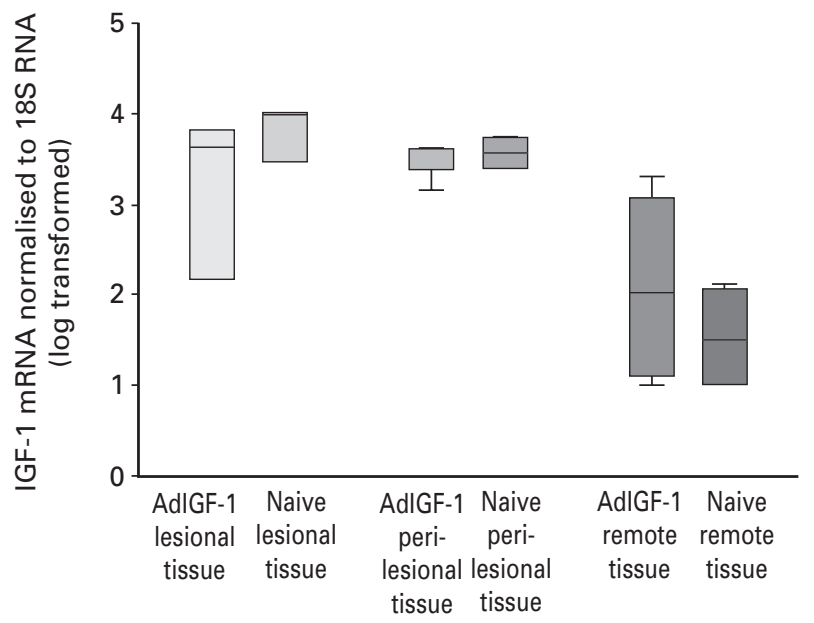

Fig. 1b

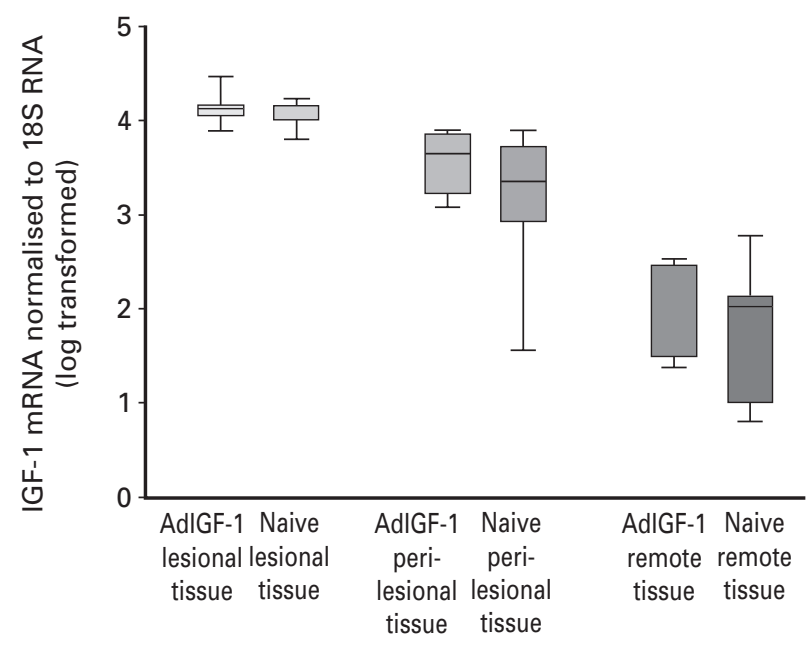

Fig. 1c

sections were counterstained with haematoxylin and assigned a score based on the surface area stained and the intensity of staining (Table IV).

Biochemical analyses. Frozen repair tissue, cartilage from the perilesional area $(5 \mathrm{~mm}$ width) and cartilage remote from the lesion (medial trochlear ridge) were pulverised in liquid nitrogen in a freezer-mill (6750 Freezer Mill, Spex Certiprep, Metuchen, New Jersey), lyophilised, and portions used for glycosaminoglycan (GAG) and type II collagen assays. Proteoglycan content was determined by GAG assay of tissues harvested at eight months (insufficient tissue was available from the four- and the nine-week time points) using the dimethylmethylene blue (DMMB) spectrophotometric method on papain-digested tissue from the lesion, perilesion and remote cartilage. Known concentrations of chondroitin-4-sulphate were used to establish a standard curve. ${ }^{49}$ Each sample was run in duplicate to ensure minimal variability.
Insulin-like growth factor-1 (IGF-1) mRNA expression in joints repaired with adenovirus (Ad) IGF-1 treated, or naive chondrocytes at a) four weeks, b) nine weeks and c) eight months. Quantitative polymerase chain reaction data are shown by box and whisker plots. Lesional tissue from AdIGF-1-treated defects had significantly greater IGF-1 expression than the control defects at four weeks (* $p<0.05$ ). (18S RNA, 18S ribosomal ribonucleic acid).
The content of collagen type II was assessed in $3 \mathrm{mg}$ to $4 \mathrm{mg}$ of each lyophilised sample by cleavage in cyanogen bromide and separation of cleaved peptides characteristic of type I and type II collagen on a $12 \%$ polyacrylamidesodium dodecylsulphate gel (SDS-PAGE). Varying proportions of purified equine collagen type I and type II cleaved peptides were also run on SDS-PAGE to construct a standard curve. The percentage of type II collagen was calculated based on the relative optical intensity of the collagen type-I $[\alpha 2(1) \mathrm{CB} 3,5]$ and type-II [ $\alpha 1$ (II)CB10] peptide bands. ${ }^{50}$ Each sample was run in duplicate to minimise variability.

Gene expression. In order to analyse gene expression, tissues from the defect, perilesional and remote areas were pulverised in a freezer-mill, and total RNA was isolated using the Trizol guanidinium chloride-phenol extraction method (Life Technologies, Grand Island, New York) with subsequent purification over RNeasy columns (Quiagen, 


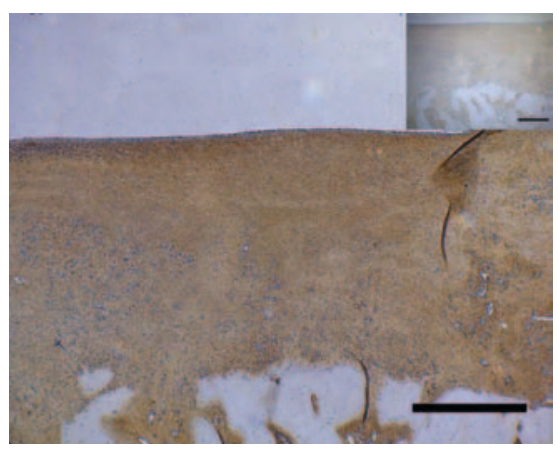

Fig. 2a

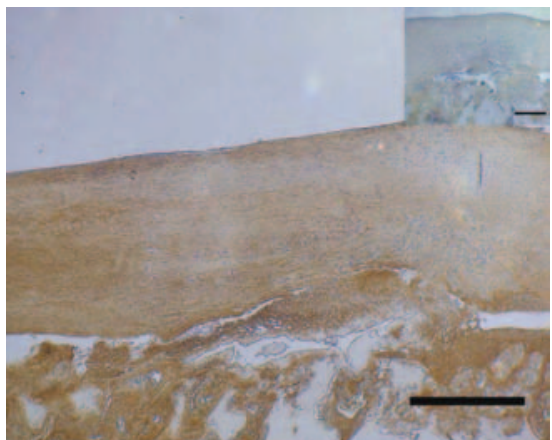

Fig. $2 d$

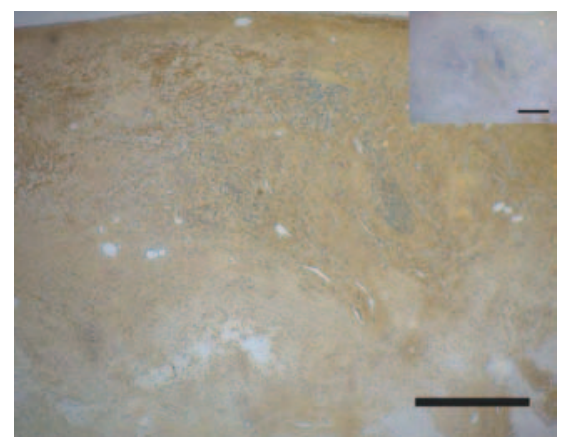

Fig. 2b

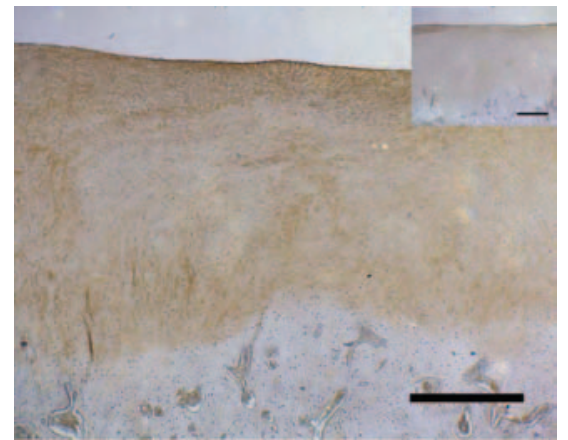

Fig. 2e

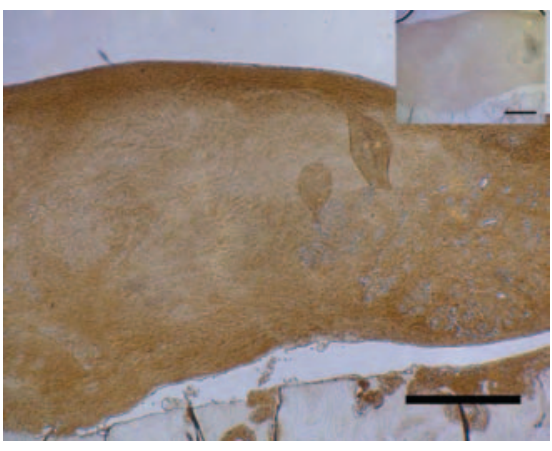

Fig. 2c

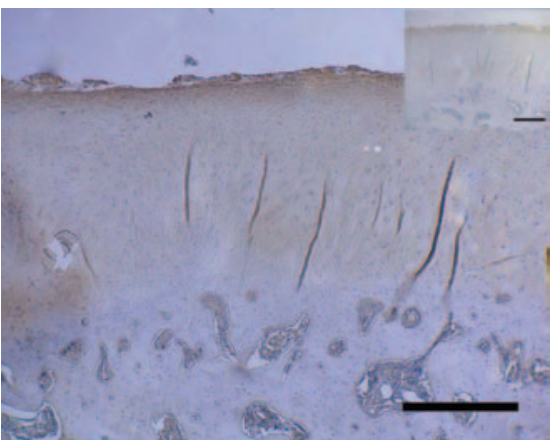

Fig. $2 f$

Insulin-like growth factor-1 (IGF-1) protein expression at four weeks (a: treated mean score $0.75( \pm 0.25)$; b: control 3.5 ( \pm 0.64$)$ ), nine weeks (c: treated mean score 2.25 ( \pm 0.91$)$; $\mathrm{d}$ : mean control score $3.0( \pm 0.9)$ ) and eight months (e: treated mean score $3.6( \pm 0.59) ;$ f: mean control score $3.12( \pm 0.54)$ ) shown by immunohistochemical reaction using chromagen diaminobenzidine and haematoxylin counter staining. Brown indicates the presence of IGF-1 protein. Defects repaired with IGF-1 genetically modified chondrocytes are shown in a, c and e and contralateral defects are shown in b, d and f. Inset photomicrographs demonstrate serial sections exposed to non-immune serum as negative controls. Bar $=200 \mu \mathrm{m}$.

Valencia, California). Purity and concentration were assessed by agarose gel electrophoresis and UV spectrophotometry. Gene expression was quantified by real-time PCR using the Taqman One-Step RT-PCR technique, and AmpliTaq Gold DNA polymerase (Absolute Quantitative PCR; ABI PRISM 7900 HT Sequence Detection System, Applied Biosystems, Foster City, California). Expression levels of IGF-1, collagen IIB, and collagen I mRNA were quantified on lesional, perilesional and remote samples at four weeks, nine weeks and eight months. Expression levels of matrix metalloproteinase-1 (MMP-1 also known as collagenase 1), MMP-3 (stromelysin), MMP-13 (collagenase $3)$, tissue inhibitor of matrix metalloproteinase-1 (TIMP-1) TIMP-3, and aggrecanase-1 (a disintegrin and metalloprotease with thrombospondin-like repeat or a disintegrin-like and metalloprotease domain (reprolysin-type) with thrombospondin type 1 motifs (ADAMTS-4) mRNA were quantified on lesional, perilesional and remote samples at four and nine weeks only. All samples were run in duplicate, and duplicates did not vary more than $0.004 \%$ to $0.007 \%$ in value. The equine primers and dual-labelled fluorescent probe [6-carboxyfluorescein (FAM) as the 5' label (reporter dye) and 5-carboxytetramethylrhodamine (TAMRA) as the 3' label (quenching dye)] were designed using Primer Express Software Version 2.0 (Applied Biosystems, Foster City, California).

The total copy number of mRNA was obtained for each gene of interest from a previously validated standard curve, and these values were normalised to $18 \mathrm{~S}$ RNA expression. In addition, a standard curve was performed for each gene at the same time of analysis.

Synovial fluid analysis. Total and differential leucocyte count and synovial fluid smear analyses were performed by routine Coulter (Beckman Coulter Inc., Fullerton, California) counting and assessment of Giemsa-stained (LIDE Laboratories Inc., Florissant, Missouri) smears, respectively.

Statistical analysis. A paired $t$-test was carried out on all parametric data at each four-week, nine-week, and eightmonth time point. Wilcoxon's signed rank test was performed on all non-parametric data. Results are expressed as a mean for four samples per group at the four- and nineweek time points, and as a mean for eight samples per group at the eight-month time point. Significance was determined when $\mathrm{p}<0.05$. 


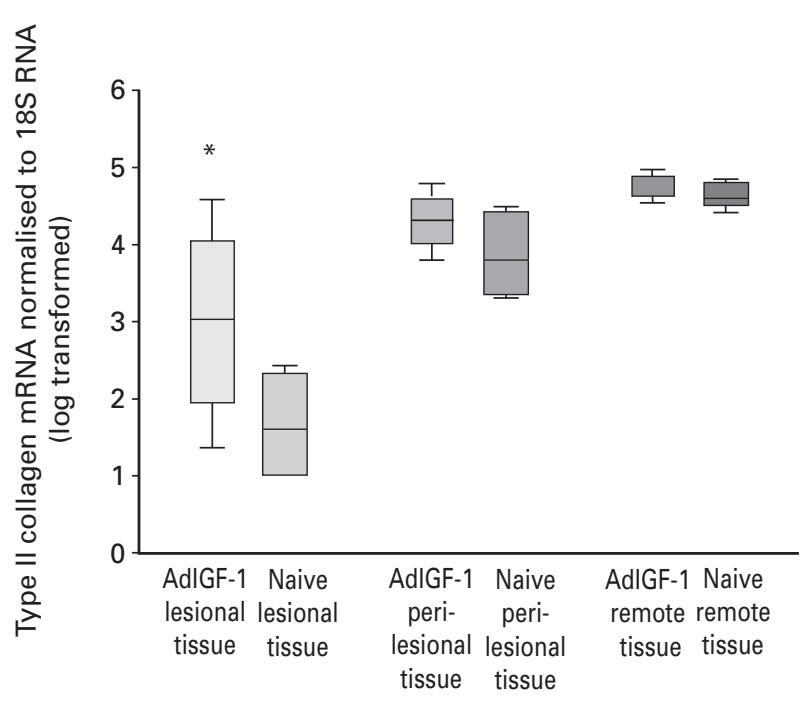

Fig. 3a

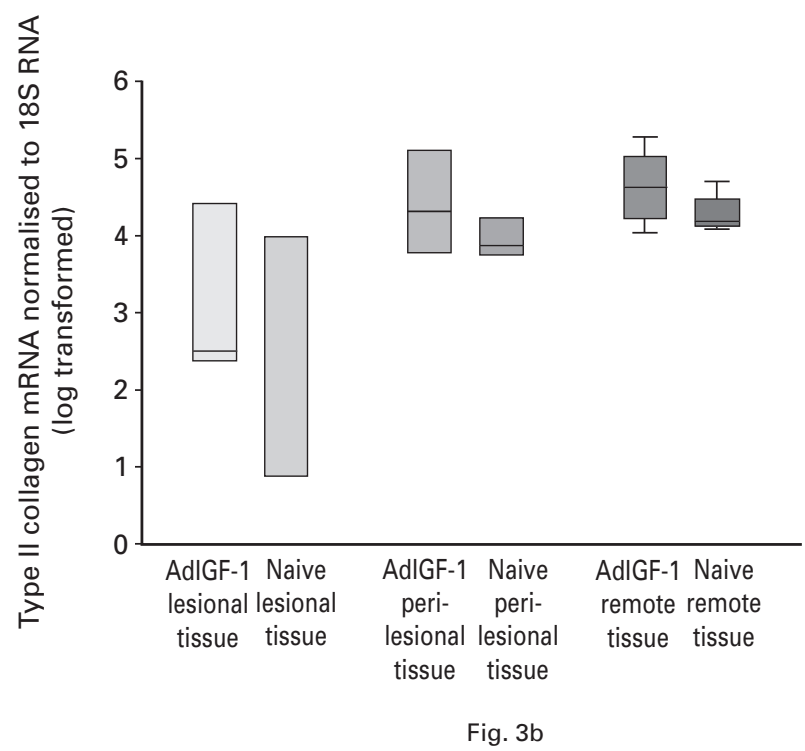

Quantitative polymerase chain reaction (PCR) data showing collagen type II mRNA expression in joints repaired with treated or naive chondrocytes at a) four weeks, b) nine weeks and c) eight months. Collagen type II expression was significantly improved in adenovirus insulinlike growth factor-1 (AdIGF-1)-transduced defects at four weeks, and tended to be higher than in naive implanted defects at nine weeks * $^{*}$ $\mathrm{p}<0.05$ ). (18S RNA, 18S ribosomal ribonucleic acid).

\section{Results}

IGF-1 expression. IGF-1 mRNA expression was ten times higher in repair tissue from lesions treated with AdIGF-1genetically modified chondrocytes than in defects repaired with naive chondrocytes at four weeks (Fig. 1a, p =0.0498). Mean IGF-1 mRNA expression at nine weeks (Fig. 1b) and eight months (Fig. 1c) was highest in the lesion and lowest in the remote tissue from the lesion for both time points, but no difference in IGF-1 expression was noted between treated and control repair tissues.

Expression of IGF-1 mRNA was localised in the repaired lesions by in situ hybridisation. At four weeks IGF-1 expression was apparent throughout the depth of the AdIGF-treated repair tissue. In contrast, IGF-1 mRNA was expressed primarily at the base of the control defects. At nine weeks and eight months, the intensity of cell-specific hybridisation in the repair tissue of the defects was similar between the treated and control groups.

At four and nine weeks AdIGF-1 genetically modified repair tissue also tended to show more IGF-1 immunoreactivity than naive controls (Figs $2 \mathrm{a}$ to $2 \mathrm{~d}, \mathrm{p}=0.06$ ). At eight months, IGF-1 staining intensity was similar for both treated and control defects (Figs 2e and 2f).

Collagen type II expression. Collagen type II mRNA expression in AdIGF-1-modified repair tissue was 100 times higher than in naive chondrocyte repair tissue at four weeks (Fig. 3a, p = 0.0183). At nine weeks and eight months, no significant difference was found between the groups for collagen type II expression (Figs $3 b$ and 3c).

Collagen type II immunoreaction at four and nine weeks appeared increased in AdIGF-1 treated repair tissue (Figs $4 \mathrm{a}$ to $4 \mathrm{~d}$ ), and associated scores confirmed a trend toward 


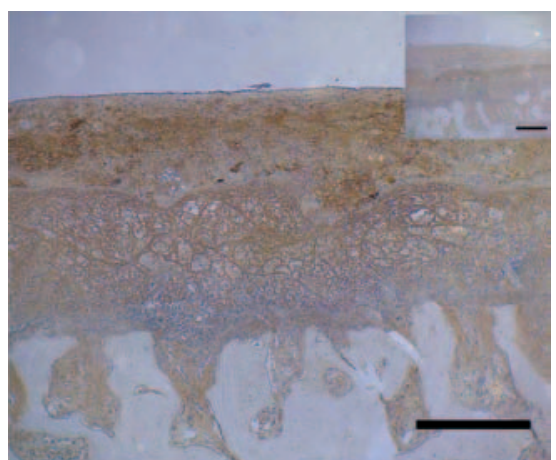

Fig. $4 \mathrm{a}$

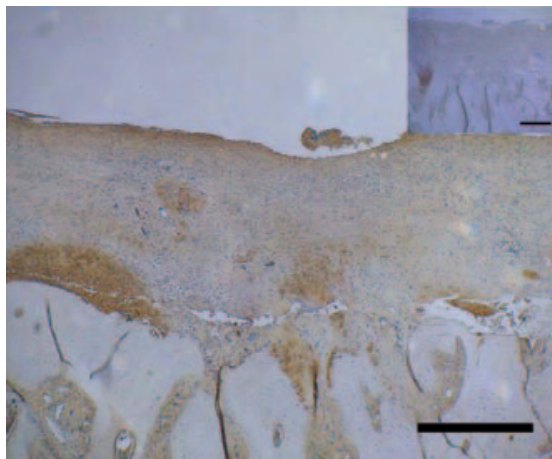

Fig. 4d

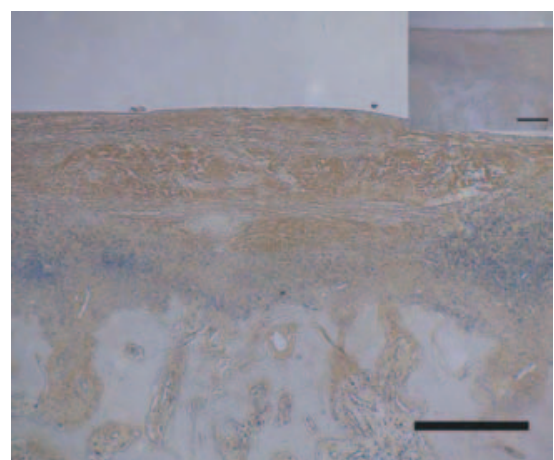

Fig. 4b

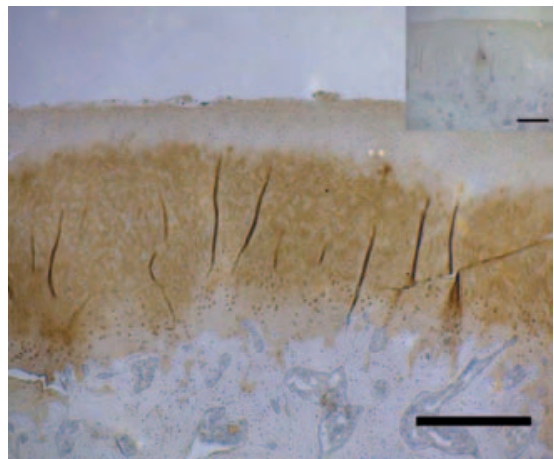

Fig. $4 \mathrm{e}$

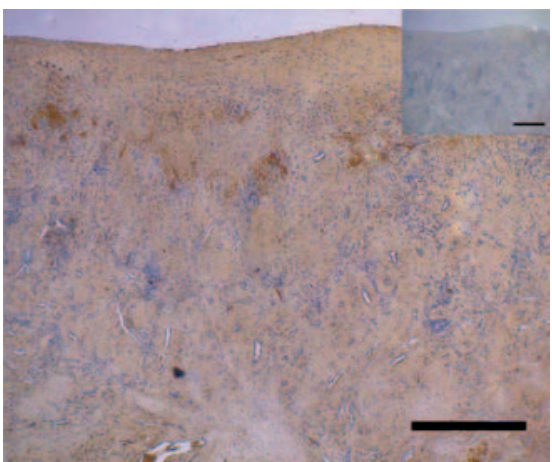

Fig. 4c

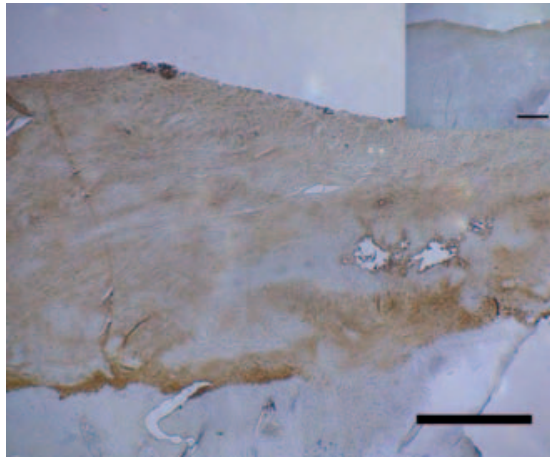

Fig. $4 \mathrm{f}$

Type II collagen protein expression at four weeks (a: mean treated score $2.5( \pm 0.2)$; b: mean control score $1.62( \pm 0.31)$ ), nine weeks (c: mean treated score $3.25( \pm 0.62)$; $d$ : mean control score $3.75( \pm 0.32)$ ) and eight months (e: mean treated score 2.37 ( \pm 0.33 ); f: mean control score $2.93( \pm 0.29)$ ) shown by immunohistochemical reaction using chromagen diaminobenzidine and haematoxylin counterstaining. Defects repaired with adenovirus insulin-like growth factor-1 (AdIGF-1) genetically modified chondrocytes are shown in a, c and e and contralateral defects are shown in b, $d$ and f). Inset photomicrographs demonstrate sections exposed to non-immune serum as negative controls. Bar $=200 \mu \mathrm{m}$.

increased collagen type II in treated tissue at both four (Figs $4 \mathrm{a}$ and $4 \mathrm{~b} ; \mathrm{p}=0.06$ ) and nine weeks (Figs $4 \mathrm{c}$ and $4 \mathrm{~d} ; \mathrm{p}=$ 0.06). Increased collagen type II immunoreactivity and associated scores were observed in the AdIGF-1-treated repair tissues at eight months (Figs $4 \mathrm{e}$ and $4 \mathrm{f}, \mathrm{p}=0.0246$ ).

The percentage of collagen type II at four weeks was ten times higher in the AdIGF-1 repair tissue (mean 16\%, SD $11.6)$ than in naive repair tissue $(1.75 \%$, SD $3.5 ; \mathrm{p}=0.06)$. In each horse the percentage of type II collagen was higher in the AdIGF-treated group than in the controls; however, variability was high, and differences at nine weeks (AdIGF-1 repair mean $13.0 \%$, SD 11.1; naive repair mean $6.3 \%$, SD 5.6; $\mathrm{p}=0.25$ ) and eight months (AdIGF-1 repair mean $26.9 \%$ SD 10.0 ; naive repair mean $22.6 \%$, SD 12.9 ; $\mathrm{p}=0.07$ ) were not statistically significant.

Gross morphological and histological outcome. Increased expression of IGF-1 and collagen type II in genetically modified repair tissue correlated with improved gross (Fig. 5) and histological outcomes (Fig. 6). Individual parameter and composite scores are presented in Table V. At nine weeks, filling of lesions repaired with AdIGF-1-modified chondrocytes (Fig. 5g), was more extensive and continuous than tissue in the control defects (Fig. 5h). Improved filling at nine weeks was also reflected in the cross-sectional filling score, which was improved in the AdIGF-1-treated group compared with the controls (Table V; $\mathrm{p}=0.090$ ). The overall gross examination scores also indicated a trend towards improved healing in the AdIGF-1 group compared with the controls $(p=0.06)$. At eight months, lesions repaired with AdIGF-1-modified chondrocytes had a significantly greater area covered with hyaline repair tissue than lesions repaired with naive chondrocytes (Table V; $\mathrm{p}=0.0240$ ). Repair with AdIGF-1-modified chondrocytes led to the development of hyaline-like tissue filling the lesion (Fig. 5i), in contrast to the controls, which were cavitated and contained yellowish repair tissue (Fig. 5j).

Histological examination at four and nine weeks (Figs 6a and $6 \mathrm{c}$ ) and histological scores (Table VI) revealed a trend towards greater defect filling for lesions repaired with AdIGF-1-modified chondrocytes compared with scores from lesions containing naive chondrocytes (Figs $6 \mathrm{~b}$ and 6d) (Table VI; $p=0.06$ ). A tendency for more fibrous filling was detected in control lesions, with the AdIGF-1-modified repair tissue tending to appear more cartilage-like at four and nine weeks. At eight months (Figs 6e and 6f), similar morphological findings were observed in both treated and 
control defects (Table VI; $\mathrm{p}=0.500$ ). Round chondrocytic cells were present in the deep layers of repair tissue and more fibroblastic cells were present in the middle and superficial layers. The junction between lesional and perilesional tissue for most joints revealed an area devoid of chondrocytes and small finger-like protrusions of fibroblastic-appearing chondrocytes extending into the perilesional tissue. Perilesional tissue adjacent to AdIGF-1 repair tissue showed a trend toward decreased chondrocytic cloning compared with perilesional tissue next to naive repair tissue (Table VI; $\mathrm{p}=0.06$ ).

Proteoglycan content. Proteoglycan content was only determined at eight months after repair (Table VII). Insufficient tissue was available for analysis at four and nine weeks. Levels were not significantly different between the groups at eight months (Table VII; $\mathrm{p}>0.05$ ). The presence of proteoglycan in repair tissue at four and nine weeks, shown by toluidine blue histochemical staining, was minimal and no differences were detected between the groups. At eight months all repair tissues had substantial proteoglycan content in the deep layer, with moderate amounts in the middle and minimal amounts in the superficial layers.

Repair tissue and surrounding cartilage enzymology. Collagen type I, MMP-1, MMP-3, MMP-13, TIMP-1, TIMP-3 and aggrecanase- 1 expression was assessed in the repair tissue and surrounding cartilage by real-time quantitative PCR. At four weeks, perilesional tissue next to control defects had a significantly higher aggrecanase-1 level than that surrounding AdIGF-1-modified defects $(\mathrm{p}=0.0498)$. All other genes were found to have similar levels of expression in similar samples from the two treatment groups.

Synovial fluid analysis. Synovial fluid total white blood cell counts four days after surgery revealed a small increase of 4000 cells/ $/ \mathrm{l}$ (SD 1000) in joints, regardless of whether they were repaired with genetically modified or naive chondrocytes. No white blood cell differences were apparent between AdIGF-1 and naive chondrocyte-implanted joints. At seven days after surgery, the counts in all joints were similar to pre-operative levels.

\section{Discussion}

Genetic modification of chondrocytes by IGF-1 gene transduction prior to transplantation cartilage resurfacing significantly increased IGF-1 transcriptional activity in repair tissue. Based on quantitative polymerase chain reaction (qPCR) and IGF-1 in situ hybridisation studies, this persisted for four to nine weeks following chondrocyte transplantation. Furthermore, IGF-1 protein levels defined by immunohistochemistry were greater in genetically modified defects at four and nine weeks. Enhanced IGF-1 transcription and translation appeared to significantly upregulate collagen type II expression (by 100-fold at four weeks), which persisted to affect type II collagen immunostaining for as long as eight months. Quantitative collagen type II assays supported immuno scores and collagen qPCR data, with strong trends toward elevated collagen type II at four weeks and eight months. The gross and histological outcome of genetically modified repair tissue also appeared to be improved over control defects. Gross filling of defects was significantly increased at four weeks, and a more hyaline-like tissue covered the lesions at eight months. Histological outcome correlated well with gross evaluation.

IGF-1 expression. IGF-1 is the major cartilage growth factor that balances anabolic and catabolic mechanisms in chondrocytes to maintain articular cartilage matrix. ${ }^{22,23}$ These experiments examined the hypothesis that IGF-1 gene transduction of chondrocytes immediately prior to implantation into cartilage defects would provide a prolonged drive to chondrocyte function and cartilage repair. The quantitative PCR results in this study, along with the in situ data, indicated a robust induction of IGF-1 mRNA transcription in the defects treated with genetically modified cells at four weeks.

The expression level of aggrecanase- 1 was significantly lower in the perilesional tissue surrounding the AdIGF-1treated defects than in controls. A recent study has shown the key role of aggrecanase- 1 in an experimental model of arthritis. ${ }^{51}$ The ability of IGF-1 to drive chondrocyte synthesis of matrix components and modulate the detrimental actions of a number of inflammatory mediators has been well documented. ${ }^{24,52-54}$ The levels of IGF-1 measured in the healing defects of AdIGF-1-treated repairs were significantly increased compared with controls, and there was a trend to higher levels in perilesional cartilage adjacent to genetically treated defects. This may have had a major role in reducing aggrecanase- 1 levels in adjacent cartilage. The ability of IGF-1 to act in an autocrine/paracrine fashion is well documented, and, we suggest, may have influenced IGF-1 and aggrecanase-1 expression in adjacent cartilage. $^{55,56}$

Antibody staining confirmed that the upregulation of IGF-1 mRNA expression correlated with the presence of IGF-1 protein in the repair tissues. Although a statisticallysignificant increase in anti-IGF-1 antibody staining was not achieved, the trend was strong $(\mathrm{p}=0.06)$, supporting our mRNA data. Increased IGF-1 mRNA expression in the AdIGF-1-treated group appeared to persist for up to four weeks, with subsequent protein expression throughout nine weeks. This length of transgene expression is typical for adenoviral vectors that do not integrate vector or transgene DNA into the host genome. The period of expression was also similar to that for adenovirus-mediated expression of bone morphogenetic protein- 7 in the same equine model, ${ }^{35}$ and in other animal models. ${ }^{57,58}$ Cellular and humoral immune responses also limit transgene expression, ${ }^{59}$ which is well illustrated in immunodeficient mice, where considerably longer term gene expression results from a single administration of replication-defective adenovirus..$^{60,61}$

IGF-1 upregulation at four weeks correlated with elevated collagen type II mRNA. Measurements of the ratio of type II to type I collagen at four weeks were also consistent with an increase in type II collagen. We and others have pre- 

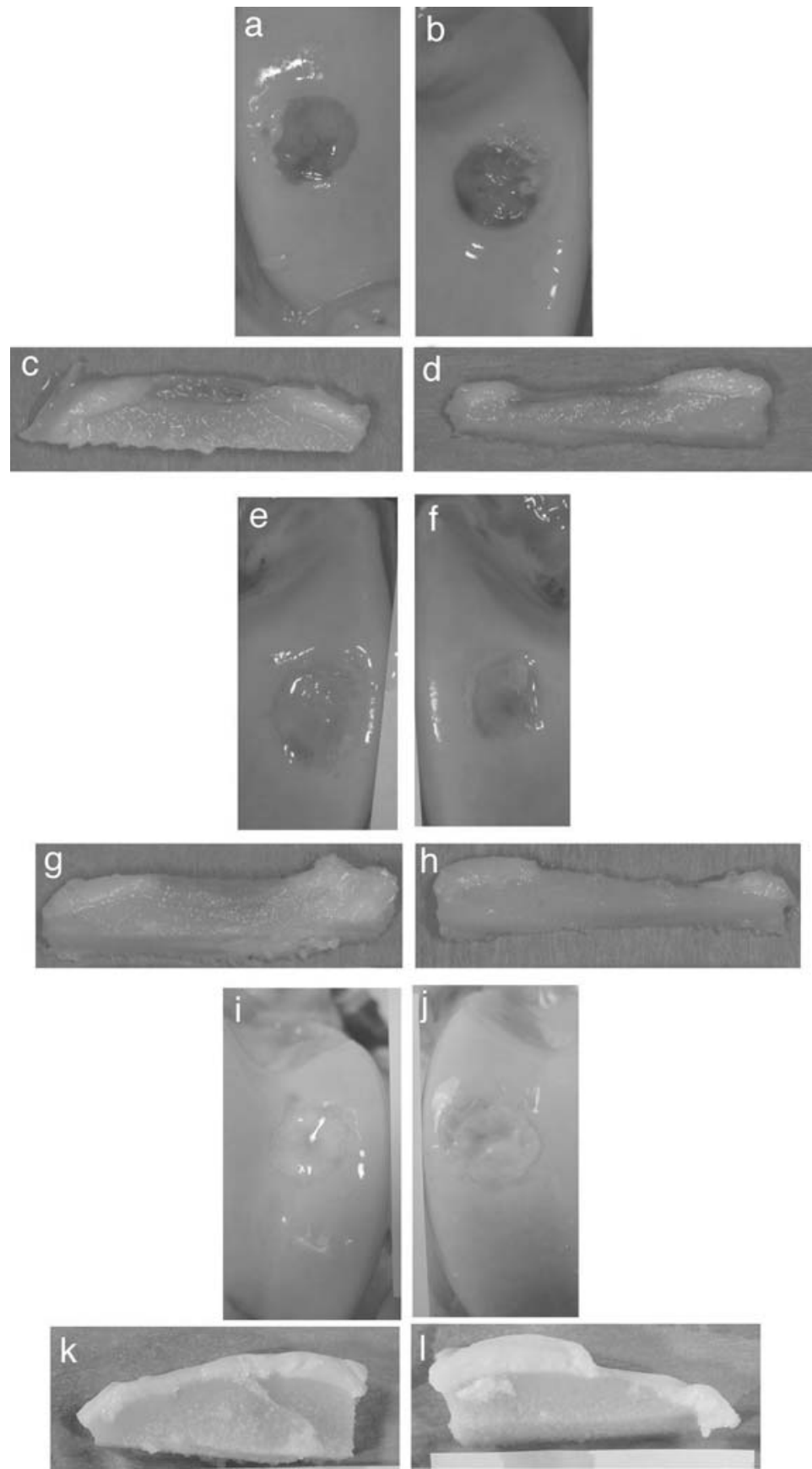

Fig. 5

Gross images of lesional and perilesional tissue en face and in cross-section at (a to d) four weeks, (e to h) nine weeks and (i to I) eight months. Defects repaired with genetically modified chondrocytes are on the left $(a, c, e, g, i, k)$ and the contralateral limbs repaired with naive chondrocytes are on the right $(b, d, f, h, j, l)$. Lesions repaired with adenovirus insulin-like growth factor-1 (AdIGF-1) genetically modified chondrocytes had improved scores over lesions repaired with naive chondrocytes at nine weeks and eight months $(p=0.06)$. 


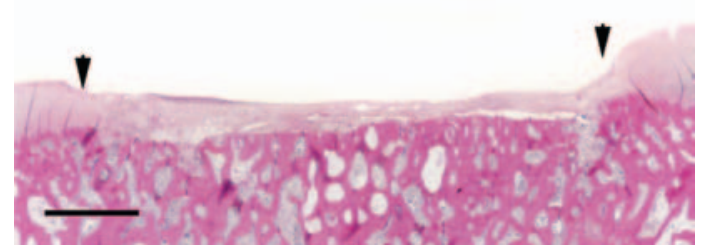

Fig. 6a

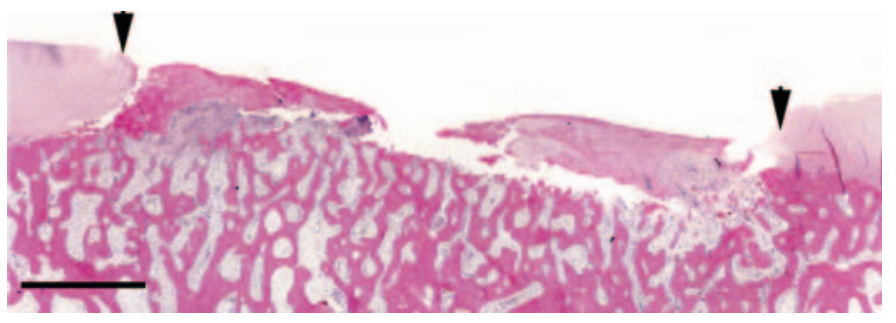

Fig. 6b

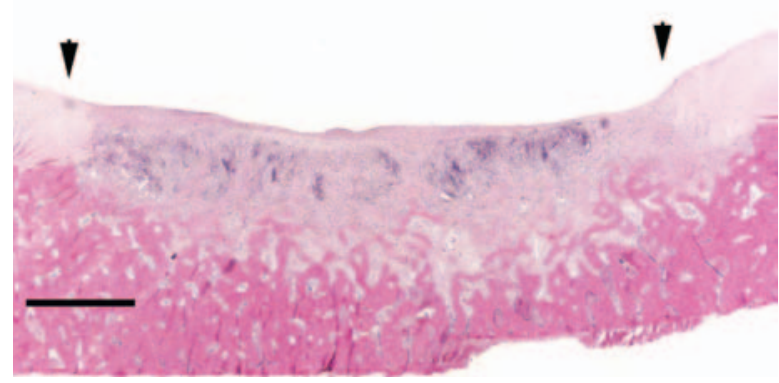

Fig. 6c

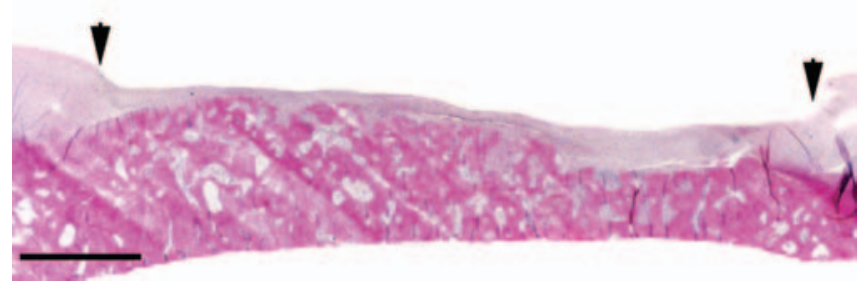

Fig. 6d

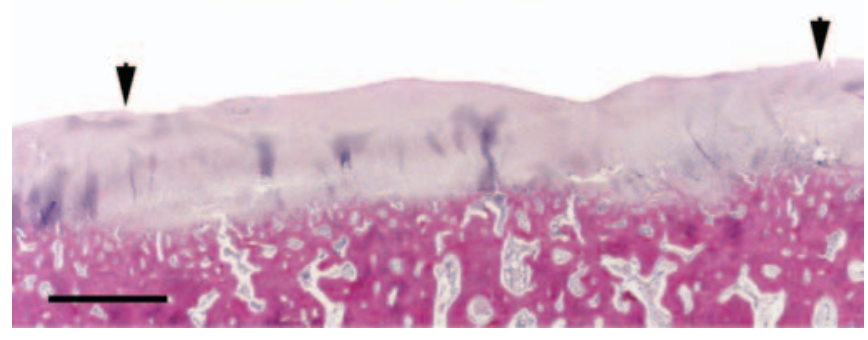

Fig. 6e

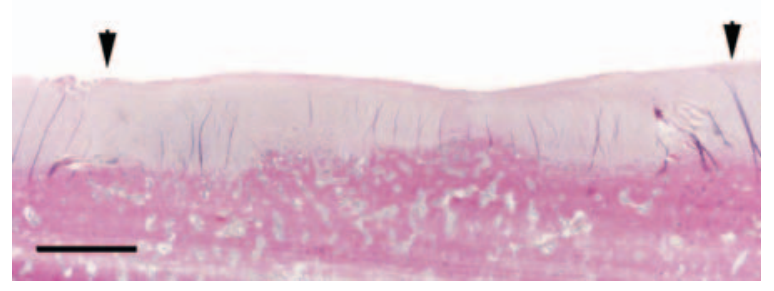

Fig. $6 f$

Morphology of osteochondral sections after repair of equine cartilage defects at a) and b) four weeks, c) and d) nine weeks and e) and f) eight months, with a), c) and e) genetically modified chondrocytes or b), d) and f) naive chondrocytes. Scores revealed that defects repaired with genetically modified chondrocytes had improved filling of the defects at four and nine weeks $(p=0.06, b a r=5$ mm). Arrows depict the interface between repair and perilesional tissue.

Table V. Scores of gross lesions at four and nine weeks and eight months (mean, SD)

\begin{tabular}{|c|c|c|c|c|c|c|c|c|}
\hline Treatment ${ }^{*}$ & Time point & $\begin{array}{l}\text { Percent area } \\
\text { covered } \\
\text { with hyaline } \\
\text { repair tissue }\end{array}$ & $\begin{array}{l}\text { Percent area of } \\
\text { defect covered }\end{array}$ & $\begin{array}{l}\text { Graft-recipient } \\
\text { tissue integration }\end{array}$ & $\begin{array}{l}\text { Cross-sectional } \\
\text { subchondral } \\
\text { bone attach- } \\
\text { ment }\end{array}$ & $\begin{array}{l}\text { Cross-sectional } \\
\text { perimeter } \\
\text { attachment }\end{array}$ & $\begin{array}{l}\text { Cross-sectional } \\
\text { filling }\end{array}$ & Total score \\
\hline AdIGF-1 & 4 weeks & $3.0(0)$ & $1.25(0.95)$ & 0.75 (1.19) & $0.75(0.86)$ & $0.50(0.70)$ & $1.50(1.15)$ & $7.5(3.62)$ \\
\hline Naive & 4 weeks & $3.0(0)$ & $1.5(0.70)$ & $1.0(1.08)$ & $0.62(0.62)$ & $0.37 \quad(0.75)$ & $1.87(0.47)$ & 8.62 (3.25) \\
\hline AdIGF-1 & 9 weeks & $2.12(0.62)$ & $0.12(0.25)$ & $0.25(0.28)$ & $0.12(0.25)$ & $0.12(0.25)$ & $0.50(0.70)^{\ddagger}$ & $3.25(2.02)^{\ddagger}$ \\
\hline Naive & 9 weeks & $2.87(0.25)$ & $0.62(0.75)$ & $0.75(0.64)$ & $0.87(0.47)$ & $0.12(0.25)$ & $1.8 \quad(0.85)$ & 7.15 (1.10) \\
\hline AdIGF-1 & 8 months & $2.0(0.30)^{\dagger}$ & $2.0(0.37)$ & $1.43(0.49)$ & $0.25(0.37)$ & $0.25(0.37)$ & $0.87(0.99)$ & $5.56(1.63)$ \\
\hline Naive & 8 months & $2.37(0.35)$ & $2.37(0.35)$ & $1.62(0.44)$ & $0.37(0.44)$ & $0.37 \quad(0.44)$ & 1.0 & $6.12(1.86)$ \\
\hline
\end{tabular}

* AdIGF-1, adenovirus insulin-like growth factor-1

† significance $(p<0.05)$

$\ddagger$ indicates trend detected between $p=0.05$ and $p=0.1$ 
Table VI. Histological scores* at four and nine weeks and eight months (mean, SD)

\begin{tabular}{|c|c|c|c|c|c|c|c|c|c|c|}
\hline $\begin{array}{l}\text { Treat- } \\
\text { ment } \dagger\end{array}$ & $\begin{array}{l}\text { Time } \\
\text { point }\end{array}$ & Defect filling & Chond pred & $\begin{array}{l}\text { Periles clon- } \\
\text { ing }\end{array}$ & $\begin{array}{l}\text { Subchondral } \\
\text { bone attach- } \\
\text { ment }\end{array}$ & Peri attach & Tol staining & Surf fib & Tide $\mathbf{m k}$ & Total \\
\hline AdIGF-1 & 4 weeks & $0.87(1.10)^{\ddagger}$ & $2.37(0.62)$ & $1.87(0.25)$ & $1.75(2.06)$ & $0(0)$ & $2.62(0.75)$ & $0.50(0.7)$ & $3(0)$ & $12.87(2.87)$ \\
\hline Naive & 4 weeks & $2.0(1.15)$ & $2.75(0.28)$ & $1.62(0.25)$ & $1.0(2.0)$ & $0.50(1.0)$ & $2.62(0.75)$ & $0.37 \quad(0.47)$ & $3(0)$ & $13.75(4.01)$ \\
\hline AdIGF-1 & 9 weeks & $0.75(0.86)^{\ddagger}$ & $3.0(0)$ & $2.25(0.50)$ & $0.75(1.60)$ & $0.12(0.25)$ & $3.0(0)$ & $0.75(1.19)$ & $3.0(0)$ & $13.87(4.46)$ \\
\hline Naive & 9 weeks & 1.75 (1.19) & $2.87(0.25)$ & $2.37(0.25)$ & $1.37(1.50)$ & $0.50(0.57)$ & $3.0(0)$ & $0.75(0.86)$ & $3.0(0)$ & $15.25(2.17)$ \\
\hline AdIGF-1 & 8 months & $1.12(1.06)$ & $1.93(0.111)$ & $1.81(0.37)$ & $0.06(0.17)$ & $0.62(0.74)$ & $2.62(0.75)$ & $1.25(0.96)$ & $3.0(0)$ & 12.0 \\
\hline Naive & 8 months & 0.87 (1.18) & $2.0(0.46)$ & $2.25(0.59)^{\ddagger}$ & $0.68(1.25)$ & $0.68(0.65)$ & $2.62(0.75)$ & $1.25(1.25)$ & $3.0(0)$ & $13.18(4.45)$ \\
\hline
\end{tabular}

viously shown upregulation of type II collagen in chondrocytes with IGF-1 supplementation. ${ }^{32,53,54,62,63}$ Our data confirm in vivo that upregulation of IGF-1 by gene transfer increases type II collagen expression and accumulation in repair tissue.

Proteoglycan content in the genetically modified repair tissue was not increased over the control repair tissue at eight months. Despite this finding, increased filling of the defect was detected. Therefore, although the proteoglycan density per milligram of tissue was similar, overall there may have been higher amounts of GAG in defects that had greater filling.

AdIGF-1-enhanced cartilage repair. Upregulation of IGF-1 in chondrocytes also improved cartilage defect repair by increasing defect filling. Cross-sectional filling on gross sections was improved in the AdIGF-1-treated group at nine weeks. Our results are in agreement with a study by Madry et $\mathrm{al}^{54}$ in which an increase in tissue thickness was reported after bovine chondrocytes over-expressing IGF-1 were transplanted onto cartilage in culture. In that study, IGF-1 over-expression in chondrocytes resulted in tissue that was $77 \%$ thicker than control tissue (untransduced chondrocytes). The increase in thickness was attributed to increased cell proliferation, as the cell-to-matrix ratio was no different in tissue derived from untransduced chondrocytes. Because cell proliferation was not determined in our study, we cannot directly attribute the increase in thickness at the early time point to greater cell proliferation; however, this certainly should be considered a contributing factor. The gross increase in thickness was also confirmed by histological analysis, which showed a strong trend toward greater defect filling in the genetically modified repair tissue at four and nine weeks. Importantly, cells within the genetically modified repair tissue at four and nine weeks more closely resembled a chondrogenic phenotype than the fibrocartilaginous-like cells within the control tissue. Gene-enhanced chondrogenesis in AdIGF-1 tissue at four, and to some extent nine weeks, was confirmed by elevated collagen type II gene expression, immunohistochemistry and quantitative collagen assays.
Table VII. Proteoglycan content of lesional, perilesional and remote tissue at eight months ( $\mu \mathrm{g} / \mathrm{mg}$ dry weight mean and SD)

\begin{tabular}{lcc}
\hline & AdIGF-1 ${ }^{*}$ modified tissue & Naive tissue \\
\hline Lesional & $46(0.8)$ & $42(0.7)$ \\
Perilesional & $67(11.1)$ & $67(11.1)$ \\
Remote & $112(0.6)$ & $112(8.1)$ \\
\hline * AdIGF-1 &
\end{tabular}

Adenoviral vectors have been shown to incite an inflammatory response in various tissues. ${ }^{64-67}$ In an attempt to characterise inflammation due to the adenoviral vector construct, the cell graft itself, or both, a comparison of mRNA expression of several inflammatory molecules, including MMP-1, MMP-3, MMP-13 and aggrecanase-1, was made using quantitative PCR. These catabolic agents have been shown previously to have a primary role in cartilage inflammation and degradation. ${ }^{68-70}$ No differences in inflammatory agent mRNA expression were noted in the naive chondrocyte-implanted or AdIGF-1-transduced repair tissue. However, in perilesional cartilage, aggrecanase-1 mRNA expression at four weeks was found to be higher in naive implanted than in AdIGF-1-treated joints ( $\mathrm{p}=$ 0.0498). This may reflect a protective effect of IGF-1 in genetically modified joints. Although this effect has not been described previously, simply creating the cartilage defect in this model has biochemical and biomechanical consequences for perilesional cartilage $e^{3,5,11,31,42}$ and IGF-1 over-expression may 'protect' against the release of degradative molecules such as the MMPs that result from osteochondral wound creation and subsequent healing.

The control group in the present study comprised defects repaired with naive chondrocytes, rather than empty defects or vehicle-based controls. However, previous studies by our group provide an abundance of historical control data that support our present findings regarding the improvement of repair with AdIGF-1-modified chondrocytes. The present study revealed that IGF-1 genetically modified chondrocytes can successfully over-express IGF-1 and accelerate the early formation of hyaline-like cartilage. However, less substantial benefit at eight months suggests 
that a different IGF-1 release profile or gene-induced expression for a longer period may further improve the results at eight months.

In addition to the well-established history of this equine model, it also offers another important benefit compared with other animal models when considering their relevance to human cartilage repair. Whereas animals such as rabbits and sheep, which are often used for studies of cartilage repair, have extremely thin subchondral bone plates, the subchondral plate of the horse is thick $(0.4 \mathrm{~mm}$ to $0.6 \mathrm{~mm})$, and most closely approximates that in humans. ${ }^{36}$ This means that, unlike studies in rabbit or sheep, where removal of the calcified cartilage can result in variable penetration into the marrow space, studies in the equine model present a much more consistent initial defect that goes down to, but never through, the subchondral plate. Preservation of the subchondral plate produces a highly reproducible defect.

In conclusion, AdIGF-1 treatment induced elevated IGF-1 mRNA and protein expression in the repair tissue for at least four weeks, and this expression was associated with an upregulation of type II collagen mRNA expression for four weeks and protein expression for up to eight months. These effects appeared to accelerate some of the healing characteristics objectively measured morphologically and histologically. Differences at eight months were not as great as those at the four- and nine-week time points. Although immunohistochemistry revealed an elevated type II collagen content and there was an improved gross appearance at eight months, quantitative assay of type II collagen at eight months was not significantly increased. A limitation to clinical application defined by this study may be the duration of IGF-1 expression. Benefits of IGF-1 were apparent primarily at the earlier time points, with IGF-1 upregulation lasting for four to nine weeks (mRNA and ligand elevations, respectively). Recent vector application developments, such as adenoassociated vectors, may further increase the magnitude and longevity of IGF-1 protein expression and warrant further investigation in future studies.

This work was supported by the Harry M. Zweig Research Foundation, the Institute for Sports Medicine Research, New York, and NIH (Grant number AR049159-02). Technical assistance with histologic preparations provided by Ms Mary Lou Norman.

No benefits in any form have been received or will be received from a commercial party related directly or indirectly to the subject of this article.

\section{Supplementary Material}

e Tables showing the scoring parameters for synovial histological assessment and the sequences for equine primers and probes used in gene expression analysis are available with the electronic version of this article on our website at www.jbjs.org.uk

\section{References}

1. Brittberg M, Tallheden T, Sjogren-Jansson B, Lindahl A, Peterson L. Autologous chondrocytes used for articular cartilage repair: an update. Clin Orthop 2001;391(Suppl):337-48
2. Xia W, Liu W, Cui L, et al. Tissue engineering of cartilage with the use of chitosangelatin complex scaffolds. J Biomed Mater Res B Appl Biomater 2004;71:373-80.

3. Hendrickson DA, Nixon AJ, Grande DA, et al. Chondrocyte-fibrin matrix transplants for resurfacing extensive articular cartilage defects. J Orthop Res 1994;12:48597.

4. Guilak F, Awad HA, Fermor B, Leddy HA, Gimble JM. Adipose-derived adult stem cells for cartilage tissue engineering. Biorheology 2004;41:389-99.

5. Nixon AJ, Fortier LA, Williams J, Mohammed HO. Enhanced repair of extensive articular defects by insulin-like growth factor-l laden fibrin composites. J Orthop Res 1999;7:475-87.

6. O'Driscoll SW, Salter RB. The repair of major osteochondral defects in joint surfaces by neochondrogenesis with autogenous osteoperiosteal grafts stimulated by continuous passive motion: an experimental investigation in the rabbit. Clin Orthop 1986;208:131-40.

7. Hurtig MB, Pool RR. Pathogenesis of equine osteochondrosis. In: McUlwraith CW, Trotter GT, eds. Joint disease in the horse. Philadelphia: W. B. Saunders, 1996:335-58.

8. Peterson L, Minas T, Brittberg M, Lindahl A. Treatment of osteochondritis dissecans of the knee with autologous chondrocyte transplantation: results at two to ten years. J Bone Joint Surg [Am]2003;85-A(Suppl 2):17-24.

9. Hunziker EB. Biologic repair of articular cartilage: defect models in experimental animals and matrix requirements. Clin Orthop 1999;367(Suppl):135-46.

10. Buckwalter JA, Saltzman C, Brown T. The impact of osteoarthritis: implications for research. Clin Orthop 2004;427(Suppl):6-15.

11. Strauss EJ, Goodrich LR, Chen CT, Hidaka C, Nixon AJ. Biochemical and biomechanical properties of lesion and adjacent articular cartilage after chondral defect repair in an equine model. Am J Sports Med 2005;33:1647-53

12. Hunziker EB. Articular cartilage repair: are the intrinsic biological constraints undermining this process insuperable? Osteoarthritis Cartilage 1999;7:15-28.

13. Marcacci M, Berruto M, Brocchetta D, et al. Articular cartilage engineering with Hyalograft C: 3-year clinical results. Clin Orthop 2005;435:96-105.

14. Grigolo B, Roseti L, Fiorini M, et al. Transplantation of chondrocytes seeded on a hyaluronan derivative (hyaff-11) into cartilage defects in rabbits. Biomaterials 2001;22:2417-24.

15. Lawrence RC, Helmick CG, Arnett FC, et al. Estimates of the prevalence of arthritis and selected musculoskeletal disorders in the United States. Arthritis Rheum 1998:41:778-99.

16. Sams AE, Nixon AJ. Chondrocyte-laden collagen scaffolds for resurfacing extensive articular cartilage defects. Osteoarthritis Cartilage 1995;3:47-59

17. Bentley G, Greer RB 3rd. Homotransplantation of isolated epiphyseal and articular cartilage chondrocytes into joint surfaces of rabbits. Nature 1971;230:385-8.

18. Chesterman PJ, Smith AU. Homotransplantation of articular cartilage and isolated chondrocytes: an experimental study in rabbits. J Bone Joint Surg [Br] 1968;50-B:18497.

19. Grande DA, Breitbart AS, Mason J, et al. Cartilage tissue engineering: current limitations and solutions. Clin Orthop 1999;367(Suppl):176-85

20. Bartlett W, Gooding CR, Carrington RW, et al. Autologous chondrocyte implantation at the knee using a bilayer collagen membrane with bone graft: a preliminary report. J Bone Joint Surg [Br] 2005;87-B:330-2.

21. Morales TI, Hascall VC. Factors involved in the regulation of proteoglycan metabolism in articular cartilage. Arthritis Rheum 1989;32:1197-201.

22. Middleton JFS, Tyler JA. Upregulation of insulin-like growth factor I gene expression in the lesions of osteoarthritis human articular cartilage. Ann Rheum Dis 1992:51:440-7

23. Verschure PJ, Van Noorden CJ, van Marle J, van den Berg WB. Articular cartilage destruction in experimental inflammatory arthritis: insulin-like growth factorregulation of proteoglycan metabolism in chondrocytes. Histochem J 1996;28:835-57.

24. Fortier LA, Balkman CE, Ratcliffe A, Nixon AJ. Insulin-like growth factor-1 gene expression patterns during repair of acute articular cartilage injury. J Orthop Res 2001;19:720-8.

25. Denko CW, Boja B, Moskowitz RW. Growth promoting peptides in osteoarthritis: insulin, insulin-like growth factor-1, growth hormone. J Rhematol 1990;17:1217-21.

26. Morales T. Articular cartilage organ cultures: in vitro models of matrix homeostasis, resorption, or repair. In: Woessner J, Howell D, eds. Joint cartilage degradation. New York: Marcel Dekker, 1993:261-80.

27. Dore S, Pelletier J, DiBattista JA, et al. Human osteoarthritic chondrocytes posses an increased number of insulin-like growth factor 1 binding sites but are unresponsive to its stimulation: possible role of IGF-1 binding proteins. Arthritis Rheum 1994;37:253-63.

28. Malemud CJ. Cytokines as therapeutic targets for osteoarthritis. BioDrugs 2004;18:23-35.

29. Trippel SB. Growth factor inhibition: potential role in the etiopathogenesis of osteoarthritis. Clin Orthop 2004;427(Suppl):47-52. 
30. Nixon AJ, Lillich JT, Burton-Wurster N, Lust G, Mohammed HO. Differentiated cellular function in fetal chondrocytes cultured with insulin-like growth factor-l and transforming growth factor-B. J Orthop B 1998;16:531-41.

31. Fortier LA, Mohammed HO, Lust G, Nixon AJ. Insulin-like growth factor-I enhances cell-based repair of articular cartilage. J Bone Joint Surg [Br] 2002;84B:276-88.

32. Brower-Toland BD, Saxer RA, Goodrich LR, et al. Direct adenovirus-mediated insulin-like growth factor I gene transfer enhances transplant chondrocyte function. Hum Gene Ther 2001;12:117-29.

33. Saxer RA, Bent SJ, Brower-Toland BD, et al. Gene mediated insulin-like growth factor-I delivery to the synovium. J Orthop Res 2001;19:759-67.

34. Madry H, Kaul G, Cucchiarini M, et al. Enhanced repair of articular cartilage defects in vivo by transplanted chondrocytes overexpressing insulin-like growth factor I (IGF-1). Gene Ther 2005;12:1171-9.

35. Hidaka C, Goodrich LR, Chen CT, et al. Acceleration of cartilage repair by genetically modified chondrocytes over expressing bone morphogenetic protein-7. J Orthop Res 2003;21:573-83.

36. Frisbie DD, Cross MW, Mcllwraith CW. A comparative study of articular cartilage thickness in the stifle of animal species used in human pre-clinical studies compared to articular cartilage thickness in the human knee. Vet Comp Orthop Traumatol, 2006;19:142-6

37. Nixon AJ. Arthroscopic methods for cartilage repair. In: Mcllwraith CW, Nixon AJ Wright IM, Boening KJ, eds. Diagnostic and surgical arthropscopy in the horse. Third ed. London: Elsevier-Mosby, 2005:445-62.

38. Convery FR, Akeson WH, Keown GH. The repair of large osteochondral defects: an experimental study in horses. Clin Orthop 1972;82:253-62.

39. Hurtig MB, Fretz PB, Doige CE, Schnurr DL. Effects of lesion size and location on equine articular cartilage repair. Can J Vet Res 1988;52:137-46.

40. Hendrickson DA, Nixon AJ, Erb HN, Lust G. Phenotype and biological activity of neonatal equine chondrocytes cultured in a three-dimensional fibrin matrix. Am J Vet Res 1994:55:410-14.

41. Fortier LA, Nixon AJ, Lust G. Phenotypic expression of equine articular chondrocytes grown in three-dimensional cultures supplemented with supraphysiologic concentrations of insulin-like growth factor-1. Am J Vet Res 2002;63:301-5.

42. Gratz KR, Wong VW, Chen AC, et al. Biomechanical assessment of retrieved tissue after in vivo cartilage defect repair: tensile modulus of repair tissue and integration with host cartilage. J Biomech 2006;39:138-46.

43. Hardy S, Kitamura M, Harris-Stansil T, Dai Y, Phipps ML. Construction of adenovirus vectors through Cre-lox recombination. J Virol 1997;71:1842-9.

44. Nixon AJ, Brower-Toland BD, Sandell L. Primary nucleotide structure of predominant and alternative splice forms of equine insulin-like growth factor $I$ and their gene expression patterns in tissues. Am J Vet Res 1999;60:1234-41.

45. Nixon AJ, Lust G, Vernier-Singer M. Isolation, propagation and cryopreservation of equine articular chondrocytes. Am J Vet Res 1992:53:2364-70.

46. Sandell LJ. In situ expression of collagen and proteoglycan genes in notochord and during skeletal development and growth. Microsc Res Tech 1994;28:470-82.

47. Fortier LA, Lust G, Mohammed HO, Nixon AJ. Coordinate upregulation of cartilage matrix synthesis in fibrin cultures supplemented with exogenous insulin-like growth factor-I. J Orthop Res 1999;17:467-74.

48. No authors listed. GENBANK. http://www.ncbi.nlm.nih.gov/entrez/ query.fcgi?CMD=search\&DB=nucleotide (date last accessed 26th March 2007).

49. Farndale RW, Buttle DJ, Barrett AJ. Improved quantitation and discrimination of sulphated glycosaminoglycans by use of dimethylmethylene blue. Biochem Biophys Acta 1986;883:173-7.

50. Sams AE, Minor RR, Wootton JAM, Mohammed H, Nixon AJ. Local and regional matrix responses to chondrocyte laden collagen scaffold implantation in extensive articular cartilage defects. Osteoarthritis Cartilage 1995;3:61-70.
51. Little CB, Mittaz L, Belluccio D, et al. ADAMTS-1-knockout mice do not exhibit abnormalities in aggrecan turnover in vitro or in vivo. Arthritis Rheum 2005; $52: 1461-72$

52. Tyler JA. Insulin-like growth factor 1 can decrease degradation and promote synthesis of proteoglycan in cartilage exposed to cytokines. Biochem $J$ 1989;260:543-8.

53. Madry H, Padera R, Seidel J, et al. Gene transfer of a human insulin-like growth factor I cDNA enhances tissue engineering of cartilage. Hum Gene Ther 2002;13:1621-30.

54. Madry H, Zurakowski D, Trippel SB. Overexpression of human insulin-like growth factor-I promotes new tissue formation in an ex vivo model of articular chondrocyte transplantation. Gen Ther 2001;8:1443-9.

55. LeRoith D, Werner H, Beitner-Johnson D, Roberts CT Jr. Molecular and celIular aspects ofthe insulin-like growth factor I receptor. Endocr Rev 1995;16:143-

56. Nakae J, Kido Y, Accili D. Distinct and overlapping functions of insulin and IGF-1 receptors. Endocr Rev 2001;22:818-35

57. Sawchuk SJ, Boivin GP, Duwel LE, et al. Anti-T cell receptor monoclonal antibody prolongs transgene expression following adenovirus-mediated in vivo gene transfer to mouse synovium. Hum Gene Ther 1996;7:499-506.

58. Hitt MM, Graham FL. Adenovirus vectors for human gene therapy. Adv Virus Res 2000:55:479-505.

59. Tripathy SK, Black HB, Goldwasser E, Leiden JM. Immune responses to transgene-encoded proteins limit the stability of gene expression after injection of replication-defective adenovirus vectors. Nat Med 1996;2:545-50.

60. Kremer EJ, Perricaudet M. Adenovirus and adeno-associated virus mediated gene transfer. Br Med Bull 1995;51:31-44

61. Yang Y, Ertl HC, Wilson JM. MHC class I-restricted cytotoxic T Iymphocytes to viral antigens destroy hepacytes in mice infected with E1-deleted recombinant adenoviruses. Immunity 1994;1:433-42.

62. Yaeger PC, Masi TL, Buck de Ortiz JL, et al. Synergistic action of transforming growth factor-B and insulin-like growth factor-I induces expression of type II collagen and aggrecan genes in adult human articular chondrocytes. Expt/ Cell Res 1997:237:318-25.

63. Nixon AJ, Saxer RA, Brower-Toland BD. Exogenous insulin-like growth factor-I stimulates an autoinductive IGF-1 autocrine/paracrine response in chondrocytes. J Orthop Res 2001;19:26-32.

64. Lieberman JR, Ghivizzani SC, Evans CH. Gene transfer approaches to the healing of bone and cartilage. Mol Ther 2002;6:141-7.

65. Wu D, Razzano P, Grande DA. Gene therapy and tissue engineering in repair of the musculoskeletal system. J Cell Biochem 2003;88:467-81.

66. Lowenstein PR, Castro MG. Inflammation and adaptive immune responses to adenoviral vectors injected into the brain: peculiarities, mechanisms, and consequences. Gene Ther 2003;10:946-54.

67. Hitt MM, Addison CL, Graham FL. Human adenovirus vectors for gene transfer into mammalian cells. Adv Pharmacol 1997:40:137-206.

68. Manicourt DH, Fujimotor N, Obata K, Thonar EJ. Levels of circulating collagenase, stromelysin-1, and tissue inhibitor of matrix metalloproteinases 1 in patients with rheumatoid arthritis: relationship to serum levels of antigenic keratan sulfate and systemic parameters of inflammation. Arthritis Rheum 1995;38:1031-9

69. Matrisian LM. Metalloproteinases and their inhibitors in matrix remodeling. Trends Genet 1990;6:121-5.

70. Wilhelm SM, Wunderlich D, Maniglia CA, Eisen AZ, Goldberg GI. Primary structure and function of stromelysin/transin in cartilage matrix turnover. Matrix Supp/ 1992;1:37-44. 